\title{
Connections of Maghrebin and Sub-Saharan Intellectuals: Trajectories and Representations
}

\author{
Mansour Kedidir
}

check for updates

Citation: Kedidir, Mansour. 2021. Connections of Maghrebin and Sub-Saharan Intellectuals: Trajectories and Representations. Religions 12: 281. https://doi.org/ $10.3390 /$ rel12040281

Academic Editors: Ousmane Kane and Zekeria Ould Ahmed Salem

Received: 13 March 2021

Accepted: 13 April 2021

Published: 19 April 2021

Publisher's Note: MDPI stays neutral with regard to jurisdictional claims in published maps and institutional affiliations.

Copyright: (C) 2021 by the author. Licensee MDPI, Basel, Switzerland. This article is an open access article distributed under the terms and conditions of the Creative Commons Attribution (CC BY) license (https:/ / creativecommons.org/licenses/by/ $4.0 /)$.
Research Center in Social and Cultural Anthropology, Oran 31000, Algeria; ral@crasc.dz

\begin{abstract}
Faced with the complex reality of their countries in the grip of multifaceted crises, the intellectuals in the Maghreb and sub-Saharan Africa are baffled. Indeed, this situation, with a wealth of lessons, ought to challenge them to reflect together on the current upheavals in their societies. Nevertheless, faced with the intricacy of current problems and their heterogeneity, these intellectuals find themselves scattered. Yet, in the past, they were bound by the same objectives. Thus, if the religious elites of the Maghreb had, during the 15th century, forged links with scholars of sub-Saharan Africa, a second wave of intellectuals succeeded them to think about the liberation of Africa and the Pan-African ideal in colonial and post-colonial contexts. However, immediately after this generation disappeared, the one that followed did not resist the disenchantment of the populations and the expansion of Arabism that influenced the formation of a generation of Maghrebin thinkers. With the bankruptcy of the socialist regimes, this hiatus heralded an era of intellectuals crumbling to the point that, with globalisation in the 21st century and the eruption of a plurality of questions, they found themselves helpless in these countries. Apart from a few attempts at building common frameworks for reflection such as those of CODESRIA or the "Esprit Panaf" pavilion at the Algiers International Book Fair, links between intellectuals from the Maghreb and sub-Saharan Africa are rare. Opposed to this type of scholars, mainly Francophone and secularised, a second type of intellectuals, rather Islamised, sharing the same representations, dominate the different spaces of the countries concerned. This paper is an attempt to explore the historical trajectory of these two types of intellectuals and then explain why, in recent decades, such a connection has marked the future of the relationship between the Maghreb and sub-Saharan Africa.
\end{abstract}

Keywords: connections; non-state actor; intellectuals secularised and islamised; Maghrebin; SubSaharan; Pan-Africanism; trajectories; representations

\section{Introduction}

Assessing the damage caused by colonial epistemology on African knowledge is undoubtedly a daunting task. From the geographic division to the racial, ethnic, linguistic and religious compartmentalisation, the aftermaths are still vivid in memories. Yet, beyond the vicissitudes of history, Africa remains the continent where the populations consider their union a vital necessity, assert their Africanness in cultural diversity, and aspire to the same values of progress and freedom. Who may well understand these dimensions other than the intellectuals that culture sensitivity and development of consciousness which empowers the Africans to express themselves? The only way for these intellectuals to achieve this is by sharing the same anxiety towards the production of meaning. Moreover, trained in the same schools and forged according to the same cognitive code, African elites have a similar conception of progress and liberation of their Continent in spite of differentiated approaches. What is key in the present paper is to find out whether these change-agents have been connected to each other for the upgrading of knowledge and the emergence of a thought of the South capable of bringing an answer to the issues that are posed to their societies and to the rest of humanity.

Any connection of intellectuals is a long-term one. It is a process through which the relationships between the different actors are built and deconstructed according to the con- 
text, namely the political and socio-economic factors. As far as Maghrebin and sub-Saharan intellectuals are concerned, their connections are a perspective rather than reality. Even if this process has begun taking account of the evolution of the Maghreb and sub-Saharan Africa, but also globalisation and the structural seismicity of these areas, it would still take time for their lineaments to take shape and for their object to be developed. Nevertheless, this pattern of analysis is not applicable to all intellectuals in the two regions. To overcome this ambiguity, the following clarification needs to be made. Two schools of thought are dominant in the Maghreb and in the sub-Saharan space, namely the Secularised and the Islamised. Each of them has experienced a different itinerary, both in their formation, their ideological reading, and in their strategy.

In this paper, it is worth showing how the connections between the two categories of intellectuals were constituted in ancient history and during the post-colonial period and why the secularised has failed while the Islamised is still tempted to project himself into the Maghreb and the sub-Saharan space. The study of this subject aims to explain the weight of the connections of intellectuals in the various attempts to concretise the Pan-African ideal.

By way of argumentation, the approach is based on data provided by renowned European and African academics, some of whom had assumed political destinies. Within this framework, our interest has focused on those who have worked on Pan-Africanism, Islamic erudition and the construction of the Ummah. For the validity of the analysis, a cross reading of recent works by Maghrebin and sub-Saharan authors and contributions to research projects sponsored by CODESRIA or CRASC ${ }^{1}$ has been selected.

Theoretically speaking, this study is based on the approach of the transnational actor operating in a network (Batistella 2006). In the light of a number of academic works, two questions deserve to be asked. There is a need to look at the posture of the two types of intellectuals, secularised and Islamised, as non-State actors, the conditions in which they had woven networks and how they have invested in the regional and international scenes by transcending state borders and challenging local authorities (Roseneau 1990). On the basis of the results of the analysis, it would be of some importance to tackle, in the second question, the reasons behind the failure of the capacity of each of them for resilience in the face of the repression of the regimes in place. Moreover, since the secularised and the Islamised have crossed paths during their historical and political careers, it would be decisive to explore their interactions in order to understand their impact on the representations of each of them. In the same vein, the weight of African realities on the strategy of both types of intellectuals is of great interest for the present research. Few studies have focused on their itinerary and their postures as networked actors on an international scale. In the present paper, globalisation is not the central theme. Apart from the fact that marginalisation and impoverishment of the continent (Bénichi 2006) have been devastating for Africa, the analysis takes into account its effects on the development of networks, the abolition of spatial and temporal borders and the multiplication of actors and fields of intervention (Ambrosi 1999). In sum, these factors allowed us to explain the transnationality of the two actors in different historical contexts.

The present work starts from the hypothesis that the above-mentioned intellectuals have woven connections in ancient and recent history. In order to frame this topic, an examination of the following aspects is suggested: how the idea of connection emerged in the minds of certain actors; what their trajectories had been and how they reacted to the constraints of the colonial and post-colonial contexts; what their representations had been; whether they were able to build lasting connections; how failure of the secularised and the hegemonic temptation of the Islamised can be explained. The answer to these questions hinges on two axes. In the first axis, the analysis focuses on showing how, by connecting around the Pan-African ideal, the secularised intellectuals of the Maghreb and sub-Saharan Africa had strengthened their links during the anti-colonial struggle but suffered setbacks during the construction of the national state. In the second axis, it is important to explain how the Islamised followed a different path from the secularised. Marginalised during the colonial period and repressed by the national state, they seem to have emerged in the 
public space thanks to a new particular context. Unlike the secularist, the Islamist projects himself into the foundation of the Ummah, which concerns Muslims on the continent and far beyond.

\section{The Secularised Intellectual: From Commitment to Dispersion}

The use of the notion of the secularised intellectual answers two motivations:

- Initially, the first claims to rights and liberties, then to independence, were destined to the elites who had been trained in the colonial school, and were therefore more impregnated with the concept of secularism (Diouf 1993).

- The second applies to sub-Saharan and West African countries whose constitutions enshrine secularism, and where social actors are accustomed to using the word of secularism in their discourse (Holder and Sow 2013).

If credit must go to the secularised intellectual for having nourished the national conscience, militated for the independence of his country and reflected on the liberation of Africa by weaving links with all the intellectuals of the Continent, he has been unable, in the face of globalisation and the bankruptcy of regimes, to achieve the Pan-African ideal. In a first phase and for more than a century, he was carried away by the passion of the national project and Pan-Africanism, but experienced disenchantment in a second phase, in front of the exhaustion of the national State and the collapse of the political systems he has sometimes defended, to its detriment. At the theoretical level, this perspective offers an atypical case of an actor who, thanks to a particular geopolitical context, had been able to build a network on the continental and international scale.

Beyond the fact that the intellectual existed long before the transnational dimension was theorised, it seems that he goes beyond the current conceptual framework, both in his political and ideological motivations and in his posture. In many ways, his experience has a heuristic character. In this section, the emphasis is on highlighting this particularity. Its explanation requires the exploration of his eventful journey in order to understand how he was able to transgress the continental colonial order and experience failure after national independence, when in favour of globalisation he could have strengthened his networks (I.2).

\subsection{An Eventful Journey}

Three stages characterise this itinerary:

- The anti-colonial struggle;

- The construction of the national state;

- The revival.

\subsubsection{From the First Pan-African Ideal to the Anti-Colonial Struggle}

Born during the Chicago meeting of 1893 and the London meeting that took place three years later, Pan-Africanism gave African intellectuals the opportunity to get to know each other and to come together (Hengelela 2016).

At the beginning of the 20th century, the African intellectual had experienced another trajectory. Having found himself on the European lands, either as an emigrant, on the front line during the First World War or to continue his studies, he discovered other ideas, other horizons of freedom. Within this framework, the most important initiative to unite intellectuals from all the colonies (Africa, including North Africa and Asia) was the work of the Intercolonial Union. Having been founded between the two World Wars by the Third International and the French Communist Party, this association "aimed to bring together and politicise the natives of the French colonies" (Ageron 1988, p. 80). It was not the last option. In a global geopolitical context, characterised by the rise of communism, new ideological perspectives opened up for these intellectuals. Thus, at the International Congress held in Brussels in February 1922, organised by the Komintern, these intellectuals made a commitment to fight against imperialism and to work for the emancipation of their people. This recommendation was also consecrated at the fifth Pan-African Congress in 
Manchester in 1945 (Dieng 2011). In this context, Pan-Africanism was imbued with the ideas of the European left and became the crucible for the formation of anti-colonialist elites (Dewitte 1995).

From the previous historical retrospective, one can posit that the diaspora supporters of the secularised current behaved as actors by virtue of their social status conferred by their political action and their role imposed by a behaviour modelled by the expectations of their colonised societies (Passeron 2001).

After the Second World War, colonialism became radical in the face of the first demonstrations for equal rights and freedoms expressed by the representatives of the colonised populations. Faced with this situation, intellectuals, trained in the European style, were better placed to react to colonial regimes. With regard to these meetings, four major events are worth mentioning. The first took place in 1953 in Kumasi, Ghana (Sherwood 2016). Organised by N'Krumah, this conference, bringing together intellectuals and politicians, had focused on the development of West Africa and the coordination of nationalist movements. The second Conference was held in Accra in April 1958, bringing together delegates from newly independent countries of Africa (including North Africa: Morocco Tunisia, Libya and Egypt), as well as representatives of the liberation movements including that of Algeria. This meeting confirmed the delegation's adherence to the principles of the United Nations Charter and adopted resolutions on self-determination of the colonised countries (Sherwood 2016). What should be retained from these events is that, throughout the 1950s, they had constituted an African connection even though cleavages started to emerge.

Several newspapers played an important role in bringing intellectuals closer together. For various reasons, many had a short life (Martin 2016). Among them, Présence africaine deserves attention. While it was a forum for dialogue and exchange among writers, politicians and thinkers, it also enabled its sponsors to organise two congresses, one in Paris in 1956 and the second in Rome in 1959 (Martin 2016). In this field where the press was to become a political instrument, it is important to turn our attention to El Moudjahid, a newspaper created by the FLN in June 1956 to express the vision and positions of the Algerian Revolution organs (Remaoun 2015, pp. 135-36). From its first release until the Algerian independence, North Africa and Sub-Saharan Africa occupied an important place in the newspaper. Whether in their first gatherings, regional conferences or through journals and newspapers, the commitment to the struggle against colonialism had constituted the basic consensus that would unify the African intellectuals. This link sustained their solidarity during the postcolonial period yet did not last long enough.

From the above remarks, it emerges that the secularised intellectual has become a transnational actor. In this posture, he has not only freed himself from the constraints of the colonial order, but has also given rise to new forms of identification (Cohen 2005). As such, one is in front of a particular type of actor who has been able to transcend his differences to mobilise in the anti-colonial struggle. However, faced with the vicissitudes of the national state, his ideological positions will soon affect his Pan-African project.

Most important is that the work of the networked actor is complex. Although it is difficult to define its complexity because of the trajectories of each group and the interweaving of their interests and the values they articulate, in the African example, one may witness mobilisation of resources for the liberation of colonised countries, which is a priority on the agenda of the proponents of the cause... (Colonomos 1998). This reality is corroborated by analysts who affirm the strength of "the dynamics of changes of affirmation and withdrawal characterising the lives of groups and individuals" in the functioning of networks. (Colonomos 1998, p. 217). However, beyond these aspects, it should be mentioned that this actor was at the origin of the turbulence that had affected inter-state relations in the African sphere dominated by the colonial order.

\subsubsection{The Postcolonial Period}

This was a crucial phase in the development of relations between African intellectuals, most of whom had become politicians or even heads of states. For more than two decades, 
the relations between elites in the Maghreb and more particularly in sub-Saharan Africa have witnessed an intense development. This rapprochement was mainly promoted by the bipolarity and the emergence of the Non-Aligned movement. In this geopolitical context, intellectuals from the above-mentioned regions, gathered in regional and international forums, debated, not without an ideological overload of preoccupations of the New Independent States, and defended economic and social development policies. For intellectuals who suffered during the colonial night, it is certain that the subjects discussed could not go beyond the recurring theme of Africa total liberation; Pan-Africanism remained their political grammar. As an Algerian academic C. Slimane pointed out, the demands during the two post-colonial decades were part of the continuation of the phase of the struggle for national independence that underpinned the foreign policy of African countries and the debates of intellectuals (Chikh 1999). Whether at Pan-African Festivals, summits of the Organization of African Unity (OAU), or at meetings between academics, writers and artists, ideology was present; it irrigated the passionate discussions and determined the vote on the resolutions that always dealt with the struggle against neo-colonialism and imperialism. This approach by Maghrebin and African elites, who were secularised, did not produce the expected results. At the origin of certain dogmatism in the perception of the complex reality of African societies and the marginalisation of intellectuals who did not share the same approach, it rang the decline of this school of thought as early as the mid-1980s (Copans 1990).

A close analysis of the results of two decades of participation of the secularised intellectuals in the construction phase of the national State makes it difficult to issue a final judgment without referring to their positions. However, some explanations can be given. First, for any intellectual who participated in the war of liberation, the passion to contribute to the national effort prevailed over the debate of ideas that some considered pure rhetoric in the face of the problems that awaited the new state, such as the struggles against misery, famine and illiteracy. Enchanted by his role as provider of ideas, he imported projects of institutions or of economic and social policies (of elsewhere thought) and whose realisation had produced an effect opposite to the one expected, as long as the realities of society were ignored (Copans 1990). Secondly, by contributing to the establishment of a one-track thinking thereby making his conception of the national State prevail and the national policies that ensued in a climate expunged of all sorts of criticism, the secularised intellectual has paved the way to autocracies and military regimes. This situation opened a new page in the political instability that characterised African history (including North Africa). Since then, one has witnessed the disenchantment of the secularised thought. Disappointed by autocratic states, rejected by his fellow citizens who no longer believe in his role as a producer of meaning and knowledge and suspected by his colleagues who have experienced repression, the secularised intellectual is tainted by a pang of conscience. In theory, the transnational actor is defined as being free of all sovereignty (Cohen 2005, p. 7); this is not the case for the secularised that has put him at the service of the national state.

From one disappointment to another, the secularised intellectuals, in particular the subSaharan, no longer sought to maintain their solidarity as long as the ideal Pan-Africanism that united them began to evaporate. Distraught in front of the internal, regional and international plans, they experienced dispersion and vagrancy. This failure finds its justification in the condition of the transnational actor seeking to challenge the state and disrupt the international scene. In this respect, an answer has been given to the problematic of the intellectual acting as a network actor. The aim here is to show how he has forged a supranational stature by transgressing the colonial order and also how he lost hope in the Pan-African ideal before the national state.

To conclude this section, the importance of globalisation stresses its effects that are twofold. Thus, while it has affected the resilience of Maghreb and sub-Saharan societies already weakened, it has erased, thanks to communication technologies, the borders between states, reduced nationalisms, and induced world time (Laidi 1998). 
After more than a decade of wandering, a new perspective of connection of secular intellectuals from the Maghreb and West Africa is emerging.

\subsubsection{The Revival}

Although they are nascent, with regard to the capacities of the Maghreb countries, new intellectual connections are emerging in academic and cultural exchanges. They seem to us to be a new beginning. The bases of these new connections are to be sought in the granting of scholarships to African students and the organisation of academic meetings and cultural events.

Since the early 1960s, Algeria has started to receive students from several African countries at its universities. If the number of scholarships awarded was around 748 during the 1990s, it should reach 10,000 by 2017 (Chikh 1999). The beneficiary students came from sub-Saharan countries mainly and were interested particularly in natural sciences and a subsidiary in social sciences. Compared to Morocco, whose number of African students enrolled in its universities exceeds 14,000, Algeria has not become aware of the importance of higher education as a tool in the development of relations between the elites (Notes de Campus France 2017). This deficit is also found at the level of scientific research structures.

Currently, one of the few institutions that maintains relations with African organisations in the field of social science is the Centre of Research in Social and Cultural Anthropology (in French: Centre de Recherche en Anthropologie Sociale et Culturelle) (CRASC). For several years, this centre has collaborated with CODESRIA, coordinating the Frenchlanguage edition of the Africa Review Book (ARB) published twice a year and reviews of books in different fields on Africa. Among the themes studied by CRASC is the Sahara as a space for the movement of people, goods and ideas between the Maghreb and West Africa.

Alongside these academic activities that are still nascent, it is important to underline the importance of the "Esprit Panaf" pavilion, an event organised as part of the International Book Fair in Algiers, which takes place each year in October. During this event, African novelists, academics and thinkers are invited to present their works, discuss subjects related to African realities, become known, and forge links with Algerian intellectuals.

In his connections, the secularised intellectual maintains a complex co-constructive relationship with the state (Lacroix 2018). Moreover, since the national state, in most African countries, is authoritarian in nature, it is difficult to imagine the knowledge holder acting outside the tutelage of governments. This constraint brings us to the limits of his transnationality. The revival projection that has just been presented is more like an observation. It is proven that it does not address the concerns of the intellectuals in question. Therefore, it falls short of the capacities of States to promote exchange between the elites; nevertheless, it shows also how the withdrawal into the self and disenchantment that characterise the unhappy consciousness of the secularised intellectual have been at the origin of his dispersion and wandering.

\subsection{An Unconventional Vision: The Failure of the Secularised}

This dispersion in vision appears in the differentiated representations of this type of intellectual. Their analysis is divided into three parts:

1. Distanced approaches;

2. Ideological positioning;

3. Crumbling of thought.

\subsubsection{Differentiated Approaches}

In the beginning, Pan-Africanism was "a movement of ideas and emotions" (Legum 1965, p. 132). Like any grouping of reflection, it evolved according to the internal realities of colonised societies and the international geopolitical context. In this perspective, even actors forge new conceptions, informed by their perception of social situations and their philosophical or ideological conviction. In this respect, Pan-Africanism cannot escape this dynamic that characterises the evolution of any movement of ideas or politics. From 
the approaches that have marked Pan-Africanism and categorised intellectuals, it can be retained two that seem to be the most important: the conception of Sheikh Anta Diop and that of Leopold Senghor. Both authors adopt a culturalist approach even though each one of them tries to be open to other horizons by taking into account new social and political data.

Cheikh Anta Diop is an intellectual of exceptional stature (Goma-Thethet 2005). As an author of several scientific works, he was a fervent nationalist and an active Pan-Africanist who met Professor William Edward Burghardt Du Bois (Goma-Thethet 2005, p. 115). In his book: Black Africa: The Economic and Cultural Basis for a Federated State (in French: Fondements économiques et culturels d'un Etat fédéral d'Afrique noire), he defends the unity of Africa. As such, he advocates the establishment of a federal state. In claiming the recapture of African history, he notes that without historical consciousness, the different peoples of Africa, scattered and isolated, cannot have a perspective (Goma-Thethet 2005, p. 117). Stressing the importance of the history of black Africa, he noted that the historiography of ancient Egypt had been removed from the history of the continent for ideological purposes. In the same vein, he argues that history as it has been written tends to identify Africa as the initial home of humanity and civilisation. From this way of proceeding, it emerges that Sheikh Anta Diop is part of essentialist logic. Obviously, he could not avoid falling into bias especially when he advocated the cultural unity of Black Africa by excluding Arab-Berber North Africa. Through this dichotomy in the approach of the African unity, Sheikh Anta Diop seems to ignore the links that could bring Maghrebin intellectuals closer to West Africa (Goma-Thethet 2005).

In a similar stance, Leopold Senghor defends the concept of Negritude. He is a great intellectual and political figure that has marked African history and culture. Defining negritude, he writes that Negro is an intuitive reason compared to White whose reason is discursive (M'bokolo 1980). From the outset, he adopted a culturalist stance. This imprint has affected his conception of Africanness. In this regard, he states: "I have often defined Africanness as the complementary symbiosis of the values of Arabism and Negritude. I would like, in a first phase, to try to demonstrate that this symbiosis by crossbreeding was first realized at the level of races and ethnic groups" (Diagne 2006, p. 106). Vainly clamoured in the arenas of Pan-Africanism, Negritude led to a deadlock. From the exhaustive study of the two thinkers' conceptions, it emerges that Pan-Africanism went back to cultural considerations.

Faced with the political, social and economic difficulties encountered by the postcolonial African state, such a thesis cannot resist. In an international climate, full of geopolitical tensions, ideology had become a legitimate system of values. As a result, secularised intellectuals, involved in the political equation, were obliged, for many of them, to position themselves in relation to the different approaches to Pan-Africanism.

\subsubsection{Ideological Positioning}

There are two categories: Marxists and nationalists. If in the first, all those who had adhered to the Marxist philosophy must be included, the second, more heterogeneous, comprises the supporters of Arabism, the Islamised, those who declare themselves to be social democrats and the defenders of socialism.

On the subject of the Marxists, this is a generation of intellectuals (trade unionists, activists of the national liberation movement and academics) who had been won over by communist ideology, mainly in Europe, when they were either exiles or emigrants. By being part of the teams in power after national independence, or by assuming the function of an organic intellectual, this school of thought has taken up the Marxist theoretical frameworks in its analysis of North-South relations of domination, the construction of the national state and economic development by following the patterns of the countries of the former Soviet Union. In an atmosphere dominated by the Marxist vulgate, the intellectual had been characterised by an aggressive posture. By becoming dogmatic, he is boxed into ideology, rejects otherness and refutes notions such as civil society, social movements, public freedoms and democracy (Copans 1990). By this attitude, he affects the 
rapprochements between Maghrebin intellectuals and West Africa. As a result, the elites of the two regions could become compartmentalised because of ideological affiliations. The marginalisation of Islamised elites not sharing the same visions may take its revenge later. If in some African countries, Marxist intellectuals are in power, in others it is the nationalists who preside over the destiny of the country.

Concerning this second category, their posture is quite different. Within this system, it was those professing socialism who dominated in a first stage to pave the way for the Arabists. If the former were faithful to the Pan-African ideal, the latter, caught up by triumphant Arabism, reoriented their intellectual concerns towards the Arab world and consequently focused on the Israeli-Palestinian conflict. Fatally, this interest was translated by a distance of the Maghrebin intelligentsia from the African field. Obviously, in situations that require an objective examination, nationalism blinds the intelligentsia. It is because it is made up of cultural artefacts whose discontinuous historical construction has not been done without emotional charge that the African nationalist intellectual cannot escape to scattering and loneliness.

By engaging, consciously or naively, in negrification and Arabisation, the secularised intellectual sinks into "the evanescence and the desperate return of chauvinism" (Fanon 1987, p. 134). Losing his bearings, lack of a long time of settling, condition of emergence of an original thought and lack of rootedness to an ideological and cultural base, he is tossed back and forth from one camp to another attracted by the rent and privileges and used in political or religious rivalries (Fanon 1987, pp. 136-37). In a continent bled by multinationals and national oligarchies, in the face of states weakened by civil wars and terrorism, and in the midst of a population exposed to famine and disease, the secularised intellectual is helpless. What alternative is he left with to assume his role of awakening the consciousness and criticising the political power?

\subsubsection{Unfortunate Consciousness and Crumbling of Thought}

For the secularised philosophy, the phase of disenchantment can be situated from the 1980s onwards when the national project of the post-colonial state whose construction, they were so passionate about, failed. The hardening of authoritarian regimes, the imprisonment of intellectual protesters, exile and deadly silence compounded this disappointment. It was then the time of unfortunate consciousness and fragmentation of thought, aggravated by geopolitical upheavals on a global and regional scale.

During the first two decades of the national state, the secularised intellectuals of the Maghreb and sub-Saharan Africa were fully mobilised in their country's national project, most of which was based ideologically on socialism. Faced with the realities of societies devastated by the colonial exploitation, they had no choice but to mobilise all resources for economic and social development. Unfortunately, this perspective has been realised to the detriment of the enhancement of tradition and popular culture perceived as obstacles. In this projection, any intellectual who did not adhere to the same approach was marginalised, sometimes, even repressed. However, convinced of the national project and the Pan-African ideal, he soon witnessed, helplessly, political instability, insecurity and repression. This shift of power towards authoritarianism accelerated with the fall of the Berlin Wall. This event came at a time when the Maghreb and sub-Saharan African countries were already shaken by internal economic crises, exposing vulnerable societies to the measures imposed by international financial institutions. During the disturbances of the established monolithic order, the disillusioned secularised intellectual's vision (lost himself) became blurred. Questions about his existential condition follow the torments of his conscience.

What is called unhappy consciousness means the tearing between reason and everything that impacts the secularised's affect and imagination. Within this framework, we view how many thinkers, novelists and academics are tainted by a feeling of loyalty towards their community, be it religious, ethnic or national and telling the truth (Saïd 2001). When M. Diouf locates the intellectual, he describes him as "an expiatory, consensual 
and rebellious victim" (Diouf 1993, p. 37). This diachronic definition, revealing the tear, is affirmed in the dichotomy borrowed from Gramsci, which he operates between the traditional intellectual and the modern intellectual (Diouf 1993). Beyond the contradiction that makes its essence, unhappy consciousness was born of the condition of the African intellectual. If he does not share misery with his fellow citizens, he suffers repression. In addition to escape the existing regimes, he goes into exile himself (Kom 1993). Therefore, it seems that this intellectual is somewhere dragging a misfortune. Referring to Michel de Certeau's expression "the genealogical misfortune", Achille Mbembe describes this situation: "the one who makes us born and grow up somewhere and registers us, whether we like it or not, in a lineage that is impossible to choose, nor really legitimize nor separate" (Mbembe 1993, p. 87). In fact, this misadventure of the secularised intellectual is only a reflection of his existential state. Being caught between reason and tradition, he is trying to nit-pick, self-seek and get lost in questions about the meaning of life. This anguish does not seem to leave the intellectual even though he denies it.

An examination of this aspect reveals that the differentiated approaches, the ideological positioning and the crumbling of thought are indicative of the weight of cultural and identity-based particularisms and the failure to project anti-colonial nationalism on a universal scale (Badie and Smouts 1995, p. 39). These factors had been decisive in blocking the concretisation of the Pan-African project around which the secularised intellectuals gathered. In this condition, this actor undergoes "fragmentation" (Batistella 2006, p. 213). This means that by losing his networks, he found himself fragmented. Dissolved in the local, and dispersed through other spaces created by globalisation, he signed the end of his connections. From the development of the secularising perspective, the following result can be picked up: by mobilising for the liberation of Africa, the actor in question has carved out a continental stature in a given historical context. Nevertheless, after national independence, he witnessed his own disenchantment with the return of local culture and the rise of identities while being unable to grasp the changes in his society or to counter the state in order to make his philosophy prevail. This failure, therefore, led to the disconnection of intellectuals from this school of thought in the Maghreb and West Africa. From this point of view, it seems that the working hypothesis put forward in this research has been verified.

Returning to the issue in hand, i.e., that of the secularised, this actor has failed to build a regional community, the rise of the Islamised who, thanks to the return of the sacred in the crisis of the mechanisms of collective identification, has favoured his transnational conduct (Badie and Smouts 1995). Since then, one can no longer speak of Pan-Africanism since the Islamist movement has taken on a Pan-Islamic dimension.

\section{The Islamised Intellectual: From Marginalisation to Hegemony}

Rejected on the margins of society by the national state and perceived by the secularised intellectual as a retrograde actor, the Islamised had emerged in the Maghreb and sub-Saharan Africa thanks to the appearance of a multicentric world characterised by the rise of Islamism in the Arab world and the geopolitical upheavals on the international scene (Badie and Smouts 1995, p 70). In order to grasp the passage from his marginalisation to his temptation to dominate the internal and regional public space, the paper first looks at the long time and sedimentation of Islamisation whose effects had forged its transnational stature; and then in a second step, it examines the accumulations that have shaped his representations of the world. In this process, the notion of "long time" comes up quite often; it serves to clarify the accumulation effects of Islamisation.

\subsection{Long Time and Sedimentation of Islamisation in Sub-Saharan Africa}

According to F. Braudel, the long-time goes beyond the event. He defines it as follows: "It is in relation to the layers of slow history that the totality of history can be rethought as from an infrastructure" (Braudel 1958, p. 734). In this conception, he emphasises that all constraints must be taken into account: geographical, social, political, economic, etc. 
It is difficult to situate the beginning of Islamisation in sub-Saharan Africa. However, it is admitted that it began in the eighth century with the opening of new roads by Muslim merchants from northern Africa (Djebbar and Moyon 2012). Since then, caravans, Ulemas and travellers have, for centuries, criss-crossed the Sahara, thus leading to a slow and silent Islamisation of West Africa in particular. What is called, within this framework, long time is similar to a geological age when Islamisation resembles sedimentation of Islamic knowledge. A reflection on this long time leads to the following three aspects:

1. From origins to colonisation;

2. The marginalisation of Islamised during the post-colonial period;

3. Geopolitical context and hegemonic temptation of the Islamised actor.

Through these historical stops, there is an attempt to show how the posture of the Islamised has adapted to political contingencies without dissolving and disappearing.

\subsubsection{From Origins to Colonisation}

It is a long period from the Eighth to the Nineteenth century. Even if it had experienced a downturn, the Islamisation had never stopped.

In West Africa, a region called by the first Arab historians "Bilad Es Sudan", the Islamisation is the result of several socio-economic and political factors whose interaction had effects on the expansion of Islam, while the first actors (merchants, travellers), had other goals. It is admitted that the role of this propagation, which took place in an indirect way, was the effort of the Berber tribes who advanced from the north of Africa towards Bilad Es Sudan, either because they were nomads accustomed to moving across the Sahara or to erect a barrier to keep the Arabs at a distance and thus ensure the monopoly of the relations with West Africa (Cuoq 1984). In this regard, Father Joseph Cuoq notes the presence of three Berber tribes that, because of their proximity to the people of Bilad Es Sudan, have gradually settled in West Africa. There are Massuffas, Guddalas, and Lamtunas who settled on the western part of Africa near Senegal River and Niger. By inhabiting this region, these Berber tribes had facilitated the arrival of two successive conquerors: the Almoravids and the Saadians. The first entered Africa in the 11th century from the bilad of Chenguit, actually called Mauritania (Norris 1990). Moreover, having relied on the Guddala and Lamtuna, they had marked the mentalities of the local populations by a rigorous practice of Islam (Norris 1990). The second, less inclined to the expansion of Islam, the Saadians, under the reign of Al Mansour, had invaded the north of Mauritania around the year 1591, not without disaster and led an expedition to Timbuktu (Weiner 1990). Of these dynasties, the Almoravids had left indelible traces in African Islam.

With the decline of the kingdoms of the Maghreb and the conquest of its coasts by Europeans (Portuguese, Spanish) and the advent of the Ottoman Empire, incursions towards West Africa became rare. However, Islamisation had continued. It became the work of the Ulemas and the brotherhoods. Some travellers, such as Ibn Batouta and El Bakri and others reported a description of the cities where scholars and educated people flocked (Sy Habib 2014). Of all these exceptional men, an importance is given to Abdel Krim el Maghili.

After his war against the Jews of Tamentit, located in the current Adrar province, in 1492, El Maghili undertook a journey further south and went to Kano via Aïr (Moumouni 2016, p. 305). Then, returning to Gao, he was received by King Mohamed Askia and became his adviser and was thus able to exert considerable influence on the practices of Islam in the Songhai Empire (Moumouni 2016, p. 323). In many ways, the Maghili had influenced a generation of scholars such as Sheikh Osman dan Fodio (1754-1817), known as Nuru El Zaman (Light of Times). In his works, Sheikh Osman had been inspired by the thought of Abdel Krim El Maghili (Moumouni 2016). It is worth mentioning in this context Siraj al-ihamm ma yhtag fi hada Zaman the guide of the brothers on the main rules to follow at that time) (Moumouni 2016, p. 307). From the experience of el Maghili in Africa, two aspects deserve to be highlighted. First, Islamisation has never stopped and second, it has produced a generation of Ulemas who have continued to develop and spread Islamic 
knowledge. This shows that the Maghili also presents a successful example of a strong connection of Maghrebin and sub-Saharan African intellectuals.

Shortly before colonisation, the Islamic space in West Africa was already constituted. If it is up to the Sanhadja and other Berber tribes to have played the leading role, it is also worth mentioning the importance of the African groups, such as the Dioulas Wangara, the Fulb and the Wolofs of Senegambia in the dissemination of Islamic erudition (Kane 2017, pp. 39-41).

Concerning the relations that existed between Islamised North Africa and Sub-Saharan Africa, the two colonial powers: England and France, sought to break solidarity between Muslims in order to curb the agitation of religious movements, such as the Sanoussya and the Mahdya (Kane 2017). Moreover, they had adopted another way of governance that consists of co-opting Muslim scholars and politicians and even financing their pilgrimage to Mecca. This same policy has been practised with regard to Islamised intellectuals in the Maghreb. It was followed by the secularisation of the school and the creation of madrasas, in order to facilitate the emergence of Muslim elites more open to modernity. Still in this logic, the colonial system had sought to marginalise the Islamised intellectual; however, this had not prevented him from producing great works, including the erudition of Sheikh Ibrahim Niasse, known for his erudition, the author of: Kashif Al-Albas, "The Removal of Confusion" and many others" (Kane 2017, p. 21). In fact, this marginalisation had the opposite effect to what had been expected by the coloniser. Unfortunately, this same logic has been practised, consciously or unconsciously, by the postcolonial state.

The exploration of this historical period shows, in some respects, how transnational flows of trade and movement of people laid the foundations for an Islamic rootedness which would become the receptacle for the training of Islamised elites, thus strengthening the links between the Maghreb and West Africa (Grégoire and Schmitz 2000).

\subsubsection{The Marginalisation of the Islamised Intellectual in the Postcolonial Period}

Right after their independence, Africans had believed that industrialisation, the modernisation of agriculture and free schooling and health care were a panacea for the development of their countries. A few decades later, difficulties soon arose. They had perhaps ignored that culture was a formidable instrument of Western domination (Saïd 2010, p. 39). More explicitly, Kane Ousmane quoting Mudimbe states: "Even in the post-colonial period, neither Africanists nor Africans, advocating the authenticity of Africa, and more less did Afrocentrists know how to free themselves from schematic and simplifying representations of the extreme of Africa as invented by the Western epistemological order" (Kane 2003, p. 2).

Engaged in the economic and social development of the country, the national state had not paid much attention to culture. As a result, the intellectual who was resistant to these policies had no right to be cited. Within this logic, the Islamised had paid the price of repression. This ostracism stems from the fact that the national state exercised control over Islam (Papi 2010). Furthermore, a large part of the secularised elites demonised the Islamised and saw in him the source of the obstacles that blocked the access of populations to modernity. Faced with this refusal, the Islamist had adopted a low profile. He had no alternative but to assume the role of conscientious objector in a society devitalised by authoritarian states. Therefore, he invested in the poor districts of African cities and remained close to the most disadvantaged social strata.

During this period, it is difficult to affirm that there was a connection of Islamised intellectuals from North Africa and Sub-Saharan Africa. Nevertheless, regional and even global meetings between Muslims were organised, which facilitated contacts between these categories of intellectuals. In this context, mention should be made of the seminars of Islamic thought organised in Maghreb countries (De La Vérone 1980). These colloquia had played an important role in bringing together African Muslim thinkers. However, these gatherings were not the only opportunities to discuss issues related to Muslim thought. Other Arab countries had taken the initiative to sponsor Muslim intelligentsia groups such as the Saudis and Libyans. Although the Islamised intellectual took advantage of 
this to dominate the public space, the community of Muslim thinkers, formed against a background of political calculation by the donor states, produced a disparate Islamic knowledge the effects of which were devastating for Muslim societies. This posture of the Islamised operating in the shadow of repressive states would soon change with regional and international upheavals.

\subsubsection{Geopolitical Context and the Hegemonic Temptation of the Islamised Intellectual}

Islam has always been a power issue. The fact that the Islamised actor has manifested himself in a hegemonic manner in the sub-Saharan and Maghreb public space refers to several causes, including the regional and international geopolitical context and the resentment of the Islamised elites towards the nation-state.

Concerning the regional and international geopolitical context, the expansion of Islam finds its explanation in three essential factors. Before the six-day war and the October 1973 war, Arab nationalism, inspired by President Nasser and the Baath party ruling Syria and Iraq, was the dominant ideology in the Middle East and the Maghreb. With the collapse of the Syrian and Egyptian economies following the war effort, Saudi Arabia, strong in her financial power and coming to the aid of these states, was able to implement "its hegemonic ambition on the meaning of Islam on the scale of the Ummah" (Kepel 2000, p. 69). This propensity to lead Islam took shape with the implementation of the Organization of the Islamic Conference (OIC); the principle of creation was adopted in September 1969 in Rabat (Corm 2013). For the first time, States met because of religion (Corm 2013). In addition, it is in this context that the activation of Islam in West Africa must be situated. From then on, Saudi Arabia, in competition with Nasser's Egypt, was able to implement its Da'wa strategy, the milestones of which were planted with the University of Medina created in 1960 and the League of the Muslim World "Rabitat Al-alam Al-islami", two years later (Schulze 1993, p. 26). The latter institution had allowed Africans to meet for the first time in an official setting. In all respects, two great African scholars: Ahmadu Bello of Nigeria and Ibrahim Niasse of Senegal were elected members of the Constitutive Assembly (Schulze 1993, p. 26).

Compared to Saudi Arabia, the Maghreb countries, although they did not have the same geopolitical ambition in the expansion of Islam, have opened their universities to Sub-Saharans and eminent thinkers have emerged (Kane 2003). Following the regional upheavals, linked to the advent of the Islamic Republic of Iran, the war in Afghanistan and the activism of the Libyan leader El Gueddafi, West Africa has been the theatre of all Islamic influences, the consequences of which were at the origin of the emergence of the Islamised intellectual in the public arena.

What could happen during the last decade of the twentieth century and during the twenty-first century is only the result of this long time, the content of which has been previously set out in an exhaustive manner. It is about a time responsible for the radicalisation of the Islamised actor. In this transformation, one must take into account globalisation in relation to communication technologies; its effects are considerable. If it had erased borders and facilitated the exchange of ideas, it also consolidated relations between Maghrebin and sub-Saharan Islamic intellectuals to the point where they are the only ones who, currently, present a successful and solid connection. The example is given by the Jihadist organisations operating in the Sahel and whose members come from the Maghreb countries and sub-Saharan Africa.

Showing a great resilience in facing colonial repression and its marginalisation by the national state, the Islamised intellectual is the only actor who currently dominates the public space. With strong roots in society, the Islamised, whether in the Maghreb or in sub-Saharan Africa, could form a monolithic bloc. Contrary to secularised torn by cultural and ideological cleavages, the Islamised proposes, as B. Badie asserts, "to respond to the demands for meaning of populations who live in cultural alienation" (Badie and Smouts 1995, p. 55). They are crucial where exclusion and frustration are more serious (Badie and Smouts 1995). This interaction, of the effects of the accumulation of the process of Islamisation with 
a complex and violent reality, has contributed to the strengthening of the representations of the world of the Islamised and has led him to develop transnational strategies to reconquer despoiled territories.

\subsection{Representation of the World of the Islamist and Transnational Strategies}

In these regions crushed under a great deal of human suffering, religion provides the individual with an imaginative response (Anderson 2002, p. 24). Due to the presence of two religious actors; one jihadist and the other moderate, the demands differ even though they share the same view about the world. Three ideas are proposed to clarify this aspect: the first relates to the religious habitus of the Islamised intellectual, the second concerns the jihadist strategy of regional deployment and the third refers to the transnational dimension of the brotherhoods in West Africa and the Maghreb.

\subsubsection{The Religious Habitus: The Rooting of Islam in West Africa}

In analysing the Islamisation of West Africa, Bourdieu's concept of Social Habitus can be put forward (Bourdieu 2000). This refers to "a system of dispositions acquired through implicit or explicit acquisition that functions as a system of cognitive and bodily schemas or as a structured structure predisposed to function as a structure" (Ferréol and Noreck 1993, p. 93). In this framework, the role of religious education, traditional practices of consultation and the impregnation of mentalities by a cultural substratum dominated by reference to the Koran, are underlined.

In societies that have been shaped for centuries by religion, Islamic philosophy has found a breeding ground for its flourishing. From this point of view, two factors must be taken into consideration: time and adherence to the world view. The latter seems to bring a cathartic response to the individual in Africa.

Concerning time, one cannot conceive of this notion in the interpretation of the Islamisation of Africa if the Koranic principle that encourages the diffusion of the divine message as part of Jihad is not taken into account. However, this diffusion took place without a historical perspective.

In the first aspect, it is recommended for every Muslim to spread Islam. Travellers, Ulemas, caravanners and merchants have tackled this task in parallel with their activity. This undertaking has been slow, smooth and peaceful. Since it was not disturbed from the 13th century, date of propagation, it could reach the depths of African society without difficulty.

In the second aspect, a special interest is given to the concept of long time. Apart from their incursions along the western coast of Africa, the European powers (Spain, Portugal, England and France) were attracted by the discovery of other continents (the Americas, India, etc.) (Deveau 2007). Having been spared until the 19th century, in their interior regions, African Muslims did not see colonial domination coming (Deveau 2007).

As a simple representation of the world, man and God, it seems that Africans will find a source of liberation. Two principles deserve to be evoked: the equality of men and women and the prohibition of all differences based on race and the rejection of Western values.

On the first principle, most thinkers and historians do not emphasise the aspiration for equality that catalysed their conversion to Islam. In the past when the African lived crushed by several constraints and the yoke of dominators, one understands how Islam gave him a means to try to recover his dignity. In the second principle, Islam outlaws slavery. Nevertheless, this did not prevent its practice for centuries, before gradually disappearing from some West African countries.

With the simplicity of its dogma, Islam is a monotheistic religion where the practice of worship is accomplished without sacraments and ceremonies (Laroui 1982). Principles of equality and ritual practices have played an important role in the consciousness of Muslims, since despite differences in race, ethnicity, language or social status, they felt closer to each other. This reality has prevailed for centuries, but the conception of the rejection of Western values, a reaction that remains manifest today, is of a more recent origin. 
About the rejection of Western values, this is a long debate whose serenity and passion for discussion depend more on the crises of the Muslim world and political contexts. This debate has always disrupted one way or another, the relationship between Islamised intellectuals in North Africa and sub-Sahara. At the beginning of the 20th century, the Muslim defined himself in relation to the foreigner (the Western) and questioned the causes of his social and economic backwardness, his radicalisation, with colonial domination, which led him to charge the Western with all the evils striking him. The rejection of the Western values is not something new. The resulting representation has been nourished by the Islamic scholarship of some thinkers such as El Maghili, Dan Fodio, de Bello and Sheikh Ibrahim Niasse. It was decisive in the crystallisation of the image of the Western in the African Muslim imaginary (Moumouni 2016); this image still persists. Being unable to be part of a rational approach, the Islamised intellectual divides the world between Dar el Islam (house of Islam) and Dar el Harb (house of war). Anyone who does not belong to the Muslim community is considered a foreigner and his values must be rejected. In the wake of this logic, the policies advocated by the postcolonial state are considered atheistic and therefore banned.

After independence, most of the African states faced ethnic and religious problems. In the Maghreb as in sub-Saharan Africa, the religious actor claimed his role in statebuilding. However, since the ruling elites were secularised, they had not given him the importance he deserved. For with the end of colonisation and the difficulties that arose in the establishment of new institutions, priority has been given to state building and the development of the country. As for religious actors, they were pushed to the margins. By being masters in the private sphere, they escaped the state and waited for their hour of revenge. Two decades after independence, the socialist and developmentalist project failed. The Islamised saw in it the justification for his speech that he has held for a long time. It is because they have moved away from the path of Islam and wanted to follow the Western model, he hammered, that regimes in Muslim countries have failed. This perception legitimised the Ummah revendication.

Muslims have always dreamed of the advent of the Ummah. Even their most enlightened thinkers refer to it. They consider that borders are founded by colonialism to divide and dominate the Muslim World. This discourse returns as a leitmotiv in the representation of the Ummah. Before claiming to be a citizen, the Islamised intellectual claims to belong to the Muslim community. With globalisation, he has managed to create a virtual community. Alongside the demand for an Ummah and the introduction of a Khalifa, the rejection of Western values and the condemnation of the secularising policies of the national state are the elements that structure the representations of the Islamised. Strongly animated by this symbolism, the jihadist and the brotherhoods are mobilising to weave their transnational networks, each one acting according to their strategy. Although they adopt different postures, these two actors do not hesitate to disrupt the international order and bypass States.

\subsubsection{The Jihadist Strategy of Regional Deployment}

The emergence of Jihadism in the Arab-Muslim and African public space was not born out of a spontaneous generation. It stems from a long process that began with Wahhabism and its spread over the Muslim World. Consequently, when confronted with reality where Maghrebin and sub-Saharan intellectuals are victims of marginalisation and repression, its effects inevitably lead to radicalisation.

In this context, it should be stressed that the jihadists operating in the great desert area in the south of the Sahara, are made up of elements belonging to all the countries of the region. Whether it be AQMI, Ansar Dine, or El MUJAO, there are always Algerians, Tunisians, Mauritanians, Malians, Nigerians, and Burkinabes, and the list is not complete ${ }^{2}$. Can the hypothesis of a perfect connection of Islamised intellectuals be put forward?

Nourished by the Salafist current (the return to ancient Muslim sources and traditions), these groups demand the establishment of a theocratic state. Even if they give 
the appearance of sharing the same conception of the world, their connection cannot be explained by an approach of a cause-effect relationship but by an analysis addressing the complexity of Jihadism in a hierarchical order (Bourgeot 2013, p. 34). The study of the origin of the members of these groups is itself disconcerting in the sense that each group has a particular history (Bourgeot 2013). Nevertheless, they reach the same result. For the lack of alternative ways and plagued by crises that they cannot explain, they are caught up by a code of religious representation that gives them the appeasement of the torn soul and the legitimisation of their act. In many respects, the conflict in the region raises questions about the status of the jihadist and the extent of his interconnection. For the first aspect, the analysis of the resilience capacity of these groups and their actions attests to the existence of a solid hierarchy. This proves that these groups are fed by an ideology constructed by imams who produce knowledge and meaning even if they may seem a-historical and irrational. Seeing the communiqués of the Aqmi or Ansar Dine claiming the attacks committed, these movements are said to have always been supported by a discourse denoting a clear religious radicalism. As part of its interconnection, its construction dates back to the beginning of the expansion of Wahhabism in the 1960s.

By analysing the profile of some African jihadists, it is admitted that not only the nourishing matrix of their referent is Wahhabism but also that they made their first learning in the war in Afghanistan and were resourced by Islamised experiences in Algeria. The case applies well to Nigerian preacher Muhammad Yusuf, but also to leaders and members of other groups operating in the south of the Sahara (Kane 2017). With the globalisation of communication, they are comforted in their vision insofar as the exchange of information and discourse approaches them without any barrier. Due to their mobility, their religious representations and their modus operandi, the jihadist connection is consubstantial with the nature of this type of Islamised. Alongside the jihadist, another actor covets the Sahelian space.

\subsubsection{The Transnational Dimension of the Brotherhoods}

The weight of brotherhoods in the stability of Muslim societies is a proven reality. It is not surprising that Senegal, compared to other countries in the region, has less disorder linked to Islamism thanks to the role of Tidjania and the Mourides who ensure the mission of regulation and moderation in the practice of a tolerant Islam. The rootedness of the brotherhoods in West Africa dates back to several centuries. By spreading from the Maghreb, these orders wove bonds whose solidity depended on historical conjunctures. If they were more supported in the period of the Twelfth and Thirteenth century, fought during the end of the Nineteenth and the half of the Twentieth and marginalised by certain post-colonial states, they were encouraged during the last few decades.

The expansion of brotherhoods in West Africa began before colonisation. To the extent that they took their starting point from the mother zaouia in the Maghreb, the ties between their intellectuals were never severed. Three brotherhoods can enable locating the connection of Islamising intellectuals in time. The first is Sanoussya. Founded in the Green Mountains of Cyrenaica by Mohamed el Senoussi in 1841, Zaouïa El Beida (the White) wove a network until it reached Tibesti and Chad (Souriau 1990). The fact that it was active in the anti-colonial struggle in the south of the Sahara shows that its elites had maintained close relations with the Islamised of Chad, Niger and Sudan. With the advent of the post-colonial state and the end of royal rule in Libya, it died out. Currently, it is the zaouia of Mostaganem, birthplace of the ancestor of the Senoussi who aspires to continue to spread the Tarîqa Alawiya, but it is not known if it has reactivated its networks in Africa.

The second brotherhood is El Kounti, which derives from the Quadirya descendant of Oqba Ibn Nafi, their ancestor Sidi Ali el Kounti founded the Kounti in Touat in the 15th century (Marty 1920) From Touat, they had invested the north of Mali and had settled in Timbuktu (Marty 1920). By developing through several centuries their zaouïa in Mali, mainly among the Tuareg in Niger and Mauritania, the Kounti gave scholars; for instance, sidi Mokhtar whose production exceeds ten works (Marty 1920). At the level of elites 
and representatives of the zaouïa plan, religious celebrations (El Mawassim) were periodic, which had given them a great aura in the Sahara and northern Mali. During colonisation, they were the first to take up arms against the occupier. One of them is El Abidine El Kounti who led resistance against the French army in its conquest of the Niger loop by the end of the 19th century. Hard-pressed, they had lost their influence. Although the ties between their followers in other regions have weakened, they have not lost their importance, especially among the Tuareg tribes. Ignored by the public authorities after independence, they continue to keep their Tarîqa away from politics.

Ahmed Tidjani (1737-1815) founded the last brotherhood, by far the most important, in the Eighteenth century (Triaud 2010). It owes its expansion in the south of the Sahara to Hadj Umar. After his death, his descendants created a zaouïa in Tivaouane, Senegal (Triaud 2010). During colonisation, the Tidjani, whether in Algeria, Morocco or Senegal, were able to retain their autonomy thanks to an intermediary role in society negotiated with the colonial administration. This behaviour was strongly criticised by Algerian nationalists who did not hesitate to ignore them right after independence. Apart from the limited meetings between Tarîa Tijaniyya followers, there is no connection between Algerian and African Tidjani intellectuals. On the other hand, relations between Moroccans and Senegalese belonging to the same brotherhood are very developed.

This discontinuity in the relations between intellectuals of the brotherhoods allows drawing the following conclusion. Right after their independence, the states of Sahelian nations had held a position of mistrust towards the brotherhoods. Currently, they are becoming aware of the role the maraboutic order can play in spreading a moderate and tolerant Islam to counter religious extremism and terrorism. If this case applies well to Algeria, on the other hand, others seek to develop a brotherly network in West Africa for a geopolitical purpose.

To close this part, it should be emphasised that in relation to the secularist, the Islamist, both in his trajectories and his perceptions, represents the archetype of a non-state actor challenging the state and contesting the hegemonic powers (Badie and Smouts 1995). In a posture built up over a long period of time, at the origin of his religious habitus, he showed resilience during the colonial and post-colonial period, to erupt in the African and Maghreb space, thanks to regional and global geopolitical upheavals and the expansion of pan-Islamism. By responding, in this context, to the question of the intellectual Islamist, from the period of his marginalisation to that of his attempt to take ownership of the local and supranational public space, it seems that the above-mentioned analysis shows, to a certain extent, the relevance of the theory of the networked actor in the approach to the connections of Maghrebian and sub-Saharan intellectuals.

\section{Conclusions}

Throughout this contribution, we have tried to show how two types of intellectuals from the Maghreb and sub-Saharan Africa have made connections in different historical contexts. To address this, the analysis has focused on their representations and trajectories. In the case of the secularising intellectual, the study found that he had not succeeded in building a lasting connection, whereas the Islamised, with his strong roots in society, had shown resilience and tends to impose himself in both spaces. For the former, by building inter-regional connections in a colonial context, it has not, however, been able to bypass the national state and transcend its ideological and identity-based cleavages. With evanescent representations and a tormented trajectory, it could not resist the movement of globalisation which accelerated its dispersion. Yet, he could have adapted to it to rebuild a virtual community in order to revive the pan-African ideal.

Compared to this type of intellectual, the Islamist has taken a singular path. As has been explained, he is an actor who has been forged in the long process of the Islamisation of West Africa. With the return of the sacred to the international scene and the geopolitical upheavals in the African and Muslim world, it nurtures the ambition of a transnational stature, with the aim of recovering territories to build the Ummah. This dream has always 
inhabited Islamist movements. However, with the rise of terrorist groups in the Sahel region, it is difficult to see this projection as the image of the Islamist has been tarnished.

By explaining how the connection of the secularising intellectual has almost disappeared, and that of the Islamised subject to the control of states, was in danger of being erased, this research work opens up two perspectives. The first is to rethink the connection between Maghrebin and sub-Saharan intellectuals by going beyond their categorisation. Faced with globalisation and the changes in their societies, African intellectuals are faced with a dilemma: should they continue to interpret the complex realities in the two geographical areas or think differently about their changes? It seems that in the current context, the priority would be for the intellectual to engage in an approach that would help to address the challenges of democratisation, the fight against poverty and the promotion of sustainable economic development. In this perspective, new transnational networks will emerge in which African intellectuals will be led, with respect for otherness, to invest in the renewal of the pan-African ideal. The second perspective relates to the theory of the transnational actor. Through the richness of the trajectory of the two actors and their interaction with the local, continental and international environment, this theme opens up new avenues for scientific research. Apart from the terrorist version of Islamism, which has been the subject of an abundant literature, the other aspects of the two intellectuals' careers, despite their rich history spanning more than a century, have not been addressed. In this context, it seems to us that this subject has an undeniable heuristic value.

Funding: This research received no external funding.

Institutional Review Board Statement: Not applicable.

Informed Consent Statement: Not applicable.

Data Availability Statement: Not applicable.

Conflicts of Interest: The author declares no conflict of interest.

\section{Notes}

1 The CRASC (Research Center in Social and Cultural Anthropology) is a national research institution founded in 1992 in Oran.

2 AQMI: Al-Qaeda in the Islamic Maghreb, MUJAO: Movement for Oneness and. Jihad in West Africa.

\section{References}

Ageron, Charles-Robert. 1988. La naissance de l'Etoile Nord-Africaine. In L'Etoile Nord-Africaine et le Mouvement National Algérien. Alger Anep: Actes du Colloque du Centre Culturel Algérien de Paris, pp. 73-85.

Ambrosi, Alain. 1999. Difficile emergence des reseaux de communication democratique dans l'espace politique global. In Vers une Citoyenneté Simulée. Rennes: Apogée, pp. 99-122.

Anderson, Benedict. 2002. L'imaginaire National, Reflexions sur L'origine et L'essor du Nationalisme. Paris: La Découverte.

Badie, Bertrand, and Marie-Claude Smouts. 1995. Le Retournement du Monde, Sociologie de la Scène Internationale. Paris: Presses de la Fondation des Sciences Politiques.

Batistella, Dario. 2006. Théorie des Relations Internationales. Paris: Sciences Po, Les Presses, pp. 187-281.

Bénichi, Régis. 2006. Histoire de la Mondialisation. Paris: Vuibert.

Bourdieu, Pierre. 2000. Esquisse d'une Théorie de la Pratique. Paris: Seuil.

Bourgeot, André. 2013. Rebellions et djihadisme dans le septentrion malien. In Le Mali Entre Doutes et Espoirs. Reflexions sur la Nation à L'epreuve de la Crise du Nord. Tombouctou: Tombouctou, pp. 23-45.

Braudel, Fernand. 1958. Histoire et Sciences sociales: La longue durée. Annales 13: 725-53. [CrossRef]

Chikh, Slimane. 1999. L'Algérie Porte de l'Afrique. Alger: Casbah.

Cohen, Samy. 2005. Les Etats face aux nouveaux acteurs. Politique Internationale, $\mathrm{n}^{\circ} 17.7$.

Colonomos, Ariel. 1998. L'acteur en réseau à l'epreuve de l'international. In Les Nouvelles Relations Internationales. Pratiques et Théories. Paris: Presses de Sciences po, pp. 203-25.

Copans, Jean. 1990. La Longue Marche de la Modernité Africaine, Savoirs Intellectuels, Démocratie. Paris: Karthala.

Corm, Georges. 2013. Pour une Lecture Profane des Conflits, sur le Retour du Religieux dans les Conflits Contemporains du Moyen-Orient.. Alger: Apic.

Cuoq, Joseph. 1984. Histoire de L'islamisation de l'Afrique de l'Ouest, des Origines à la fin du XVI e Siècle. Paris: Librairie Orientaliste Paul Geuthner. 
De La Vérone, Chantal. 1980. XIII Séminaire de la pensée islamique. Revue des Mondes Musulmans et de la Méditerranée 29: 163-65.

Deveau, Jean-Michel. 2007. Traite d'esclaves et fortification dans l'Ouest africain. Echo Géo 1: 3-5. [CrossRef]

Dewitte, Philippe. 1995. Intellectuels et étudiants à Paris à la veille des indépendances. In Le Paris des Etrangers Depuis 1945. Paris: de la Sorbonne.

Diagne, Pathe. 2006. L.S Senghor ou la Négritude Servante de la Francophonie. Paris: L'Harmattan.

Dieng, Amady Aly. 2011. Mémoires d'un Etudiant Africain. Dakar: Codesria, vol. 1.

Diouf, Mamadou. 1993. Les intellectuels africains face à l'entreprise démocratique, entre la citoyenneté et l'expertise. Politique Africaine 51: 35-47.

Djebbar, Ahmed, and Marc Moyon. 2012. Les Sciences Arabes en Afrique, Mathématiques et Astronomie au IXe-XIX e Siècle. Alger: Apic.

Fanon, Frantz. 1987. Les Damnés de la Terre. Alger: Enag.

Ferréol, Gilles, and Jean-Pierre Noreck. 1993. Introduction à la Sociologie. Paris: Armand Colin, pp. 81-96.

Goma-Thethet, Joachim Emmanuel. 2005. Cheikh Anta Diop et l'avenir de l'Afrique (une relecture des fondements économiques et culturels d'un Etat fédéral d'Afrique noire). In Intellectuels, Nationalisme et idéal Panafricain, Perspectives Historiques. Dakar: Codesria, pp. 115-28.

Grégoire, Emmanuel, and Jean Schmitz. 2000. Afrique noire et monde arabe: Continuités et ruptures. Autrepart, Cahier des Sciences Humaines 6: 5-20.

Hengelela, Joseph Cihunda. 2016. Un idéal sans leadership. In L'idéal Panafricain Contemporain. Fondements Historiques et Perspectives Futures. Dakar: Codesria, pp. 143-63.

Holder, Gilles, and Moussa Sow. 2013. Les laïcités africaines vues de Bamako: Un colloque pris par son contexte. In L'Afrique des Laïcités, Etat, Religion et Pouvoirs au sud du Sahara. Edited by Gilles Holder and Moussa Sow. Tombouctou: IRD, pp. 19-36.

Kane, Ousmane Oumar. 2003. Les Intellectuels Non Europhones. Dakar: Codesria.

Kane, Ousmane Oumar. 2017. Au-delà de Tombouctou, Erudition Islamique et Histoire Intellectuelle en Afrique Occidentale. Dakar: Codesria.

Kepel, Gilles. 2000. Jihad, Expansion et Déclin de L'islamisme. Paris: Gallimard.

Kom, Ambroise. 1993. Intellectuels africains et enjeux de la démocratie: Misère, répression et exil. Politique Africaine 51: 61-8.

Lacroix, Thomas. 2018. Le Transnationalisme: Espace, Temps, Politique. Université Paris Est. June 8. Available online: Hal-Archives. $\mathrm{fr} /$ tel-01810672 (accessed on 19 April 2021).

Laidi, Zaki. 1998. Le temps mondial. In Les Nouvelles Relations Internationales. Pratiques et Théories. Paris: Presses de Sciences po, pp. 183-98.

Laroui, Abdallah. 1982. L'idéologie Arabe Contemporaine. Paris: $2^{\text {ième }}$ François Maspéro.

Legum, Colin. 1965. Le Panafricanisme à L'épreuve de L'indépendance. Paris: Saint-Paul.

M’bokolo, Elikia. 1980. L'Afrique au XXe siècle, le Continent Convoité. Alger: Office des Publications Universtaires.

Martin, Tony. 2016. Les fondemenst historiques du panafricanisme. In L'idéal Panafricain Contemporain Fondements Historiques et Perspectives Futures. Dakar: Codesria, pp. 39-63.

Marty, Paul. 1920. Etudes sur l'islam et les tribus du Soudan, tome 1, les Kounti, les Berabich, les Ighelad. Paris: E. Leroux.

Mbembe, Achille. 1993. Ecrire l'Afrique à partir d'une faille. Politique Africaine 51: 69-97.

Moumouni, Seyni. 2016. Aspects de la pensée du Cheikh Abdelkrim El Maghili dans l'œuvre du Cheikh Osman dan Fodio. In Carrefours Sahariens, vues des Rives du Sahara. Alger: Crasc, pp. 303-14.

Norris, Harry T. 1990. Abdullah ibn Yassin. In Les Africains. Paris: du Jaguar, tome 12, p. 1739.

Notes de Campus France. 2017. La Mobilité Internationale des Étudiants Africains, Hors-Series. November. Available online: https: / / ressorces.campusfrance.org (accessed on 19 April 2021).

Papi, Stephane. 2010. Le contrôle étatique de l'islam en Algérie: Un héritage de l'époque coloniale. L'Année du Maghreb VI: 491-503. [CrossRef]

Passeron, Jean-Claude. 2001. Acteur, agent, actant: Personnages en quête d'un scenario introuvable. Revue Européenne des Sciences Sociales XXXIX-121: 15-30. [CrossRef]

Remaoun, Hassan. 2015. Le regard porté sur l'Afrique par le FLN durant la guerre de libération nationale en Algérie (1954-1962). Une lecture de l'organe officiel El Moudjahid. Actes de colloque international. In Entreprise Coloniale et Luttes de Libération en Afrique. Alger: CNRPH, pp. 135-46.

Roseneau, James. 1990. Turbulence in World Politics. A Theory of Change and Continuity. Princeton: University Press.

Saïd, Edward. 2001. Des Intellectuels et du Pouvoir. Alger: Marinoor.

Saïd, Edward. 2010. Culture et Impérialisme. Alger: Apic.

Schulze, Reinhard. 1993. La Da'wa saoudienne en Afrique de l'Ouest. In Le Radicalisme Islamique au Sud du Sahara. Paris: Karthala, pp. 21-35.

Sherwood, Marika. 2016. N'krumah et le panafricanisme. In L'idéal Panafricain Contemporain Fondements Historiques et Perspectives Futures. Dakar: Codesria, pp. 87-116.

Souriau, Christiane. 1990. Mohamed Ben'Ali Es-Sanoussi (1787-1859). Fondateur d'une confrérie aux dimensions d'un empire. In Les Africains. Paris: du Jaguar, tome 6, pp. 229-59.

Sy Habib, Jacques. 2014. L'Afrique, Berceau de L'écriture et ses Manuscrits en Péril. Paris: L'Harmattan.

Triaud, Jean-Louis. 2010. La Tidjania, une confrérie transnationale. Politique Etrangère 4: 819-30.

Weiner, Jérome B. 1990. Al Mansur, un sultan du Maroc et l'or de Tombouctou. In Les Africains. Paris: du Jaguar, tome 2, pp. $223-47$. 